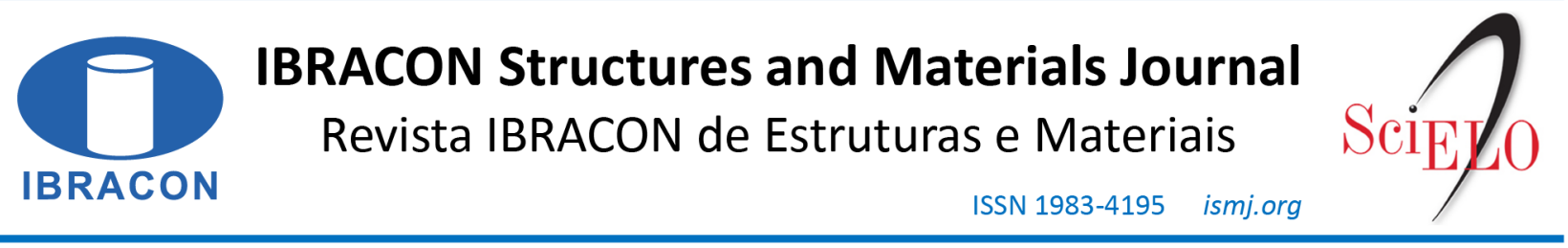

ORIGINAL ARTICLE

\title{
Analysis of cementitious matrices self-healing with bacillus bacteria
}

\section{Análise de matrizes cimentícias autocicatrizantes com bactéria Bacillus}

\author{
Vinicius Muller ${ }^{\mathrm{a}}$ (D) \\ Fernanda Pacheco ${ }^{\text {a }}$ (D) \\ Caroline Macedo Carvalho ${ }^{\mathrm{b}}$ (D) \\ Franciele Fernandes ${ }^{\mathrm{a}}$ \\ Victor Hugo Valiati ${ }^{\mathrm{b}}$ \\ Regina Celia Espinosa Modoloc \\ Hinoel Zamis Ehrenbring ${ }^{\mathrm{a}}$ (i) \\ Bernardo Fonseca Tutikian ${ }^{\mathrm{c}}$ (1)
}

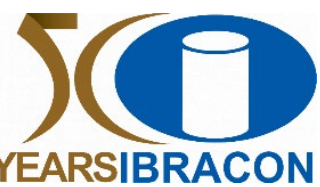

${ }^{\text {a}}$ Universidade do Vale do Rio do Sinos - UNISINOS, itt Performance; Graduação em Engenharia Civil, São Leopoldo, RS, Brasil

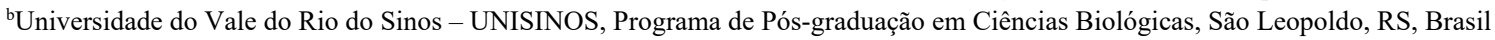

'Universidade do Vale do Rio do Sinos - UNISINOS, , Programa de Pós-graduação em Engenharia Civil, São Leopoldo, RS, Brasil

Received 05 July 2021

Accepted 01 December 2021

\begin{abstract}
Bacterial solutions have been studied to promote self-healing of cementitious matrices, however, the concentration of this solutions varied between studies. Consequently, the objective of this study was to evaluate the self-healing potential of different concentrations of Bacillus subtilis AP91 encapsulated in expanded perlite (EP). Visual examination and capillary absorption of water was measured over time. Test samples were also subjected to strength resistance tests. The physiochemical properties of EP and his distribution on the matrix was evaluated. There was no observable trend in the effect of solution concentration on the width of crack healed. However, concentration affected the quantity and length of the fissures healed. Capillary absorption decreased as fissures were healed while no significant changes were measured in strength resistance regardless of the concentration. Results indicated that EP provided suitable encapsulation to the bacterial solution and there is an adequate distribution of the capsules in the cementitious matrix.

Keywords: bacteria, concrete, durability, cracking, mortar, self-healing.
\end{abstract}

Resumo: Soluções bacterianas têm sido estudadas para promover a autocura de matrizes cimentícias, entretanto, a concentração dessas soluções variou entre os estudos. Consequentemente, o objetivo deste estudo foi avaliar o potencial de autocura de diferentes concentrações de Bacillus subtilis AP91 encapsulado em perlita expandida (PE). O exame visual e a absorção capilar de água foram medidos ao longo do tempo. As amostras de teste também foram submetidas a testes de resistência de força. Foram avaliadas as propriedades físico-químicas do EP e sua distribuição na matriz. Não houve tendência observada no efeito da concentração da solução na largura da fissura cicatrizada. No entanto, a concentração afetou a quantidade e o comprimento das fissuras cicatrizadas. A absorção capilar diminuiu conforme as fissuras foram curadas, enquanto nenhuma mudança significativa foi medida na resistência da força, independentemente da concentração. Os resultados indicaram que a EP proporcionou encapsulamento adequado à solução bacteriana e que há uma distribuição adequada das cápsulas na matriz cimentícia.

Palavras-chave: bactéria, concreto, durabilidade, fissura, argamassas, autorregenerantes.

How to cite: V. Muller et al. "Analysis of cementitious matrices self-healing with bacillus bacteria," Rev. IBRACON Estrut. Mater., vol. 15, no. 4, e15404, 2022, https://doi.org/10.1590/S1983-41952022000400004

Corresponding author: Regina Célia Espinosa Modolo. E-mail: reginaem@unisinos.br

Financial support: The authors would like to thank Unisinos, Performance Technological Institute (itt) and CNPq for the financial support granted to Regina Célia Espinosa Modolo (Grant \# 307755 / 2018-5).

Conflict of interest: Nothing to declare.

Data Availability: The data that support the findings of this study are openly available in [Unisinos repository] at

[http://www.repositorio.jesuita.org.br/handle/UNISINOS/9376], reference number [9376].

(c) (i) This is an Open Access article distributed under the terms of the Creative Commons Attribution License, which permits unrestricted use, distribution, and reproduction in any medium, provided the original work is properly cited. 


\section{INTRODUCTION}

Worldwide, concrete is the material most used material [1] due to several advantages [2]-[4]. However, it has been noted that Portland cement production accounts for $9.5 \%$ of global carbon dioxide emissions [5]. Besides these environmental considerations, additional costs are accrued when dealing with interventions in reinforced concrete. In developed countries, costs with repair, maintenance and reconstruction of structures is higher than new ones [6]. In developing countries, concrete structures tend to deteriorate ahead of their expected life cycle [3]. In monetary terms, one-third of the budget of large construction projects in the Netherlands is designated for interventions while in Great Britain, $45 \%$ of all activities are repair and maintenance [7]. Complementing, Gardner et al. [8] highlight the problem of maintenance costs, citing the United Kingdom as an example and thus justifying the need for such expenses to be minimized. The demolition/construction cycle of a project results in severe environmental costs [9] which are also believed to be associated with repair work [6].

Fissure formation and the resulting entry of harmful agents is one of the main causes of damage to reinforced concrete [10]-[16]. Thus, mitigating the occurrence and the size of fissures reduces concrete deterioration due to environmental factors [17], [18]. Fissure recovery usually involves the use of chemical products that are expensive and potentially harmful to health and the environment [16]. Consequently, new techniques to extend the durability of structures, such as self-healing concrete, are needed [19]. Self-healing can be obtained from higher cement use [20], [21], addition of pozzolans[21], [22], chemical solution encapsulation in light and porous aggregates [23] and bacterial solutions in concrete [16], [24]-[27].

Bacterial solutions inserted in cementitious compounds promote microbiologically induced calcite precipitation (MICP). Species of the Bacillus genus are capable of metabolizing MICP while at the same time being resistant to aggressive environments [28]. This bacterial genus has been widely studied and cultivated in alkaline mediums and its dormant endospores are able to survive centuries in chemically aggressive environments [29]-[32]. Like other chemoorganotrophic bacteria, this genus extracts energy from the oxidation of organic compounds [29]. The MICP reaction in cementitious compounds occurs through calcium lactate oxidation (Equation 1 and Equation 2), and calcium acetate oxidation (Equation 3 and Equation 4) [33], [34].

$$
\begin{aligned}
& \mathrm{CaC}_{6} \mathrm{H}_{10} \mathrm{O}_{6}+6 \mathrm{O}_{2} \rightarrow \mathrm{CaCO}_{3}+5 \mathrm{CO}_{2}+5 \mathrm{H}_{2} \mathrm{O} \\
& 5 \mathrm{CO}_{2}+5 \mathrm{Ca}(\mathrm{OH})_{2} \rightarrow 5 \mathrm{CaCO}_{3}+5 \mathrm{H}_{2} \mathrm{O} \\
& \mathrm{Ca}\left(\mathrm{C}_{4} \mathrm{H}_{6} \mathrm{O}_{4}\right)+4 \mathrm{O}_{2} \rightarrow \mathrm{CaCO}_{3}+3 \mathrm{CO}_{2}+3 \mathrm{H}_{2} \mathrm{O} \\
& 3 \mathrm{CO}_{2}+3 \mathrm{Ca}(\mathrm{OH})_{2} \rightarrow 3 \mathrm{CaCO}_{3}+3 \mathrm{H}_{2} \mathrm{O}
\end{aligned}
$$

In Equation 1, calcium lactate $\left(\mathrm{CaC}_{6} \mathrm{H}_{10} \mathrm{O}_{6}\right)$ oxidates into calcium carbonate $\left(\mathrm{CaCO}_{3}\right)$ with carbon dioxide $\left(\mathrm{CO}_{2}\right)$ and water $\left(\mathrm{H}_{2} \mathrm{O}\right)$ as leftover products. As shown in Equation 2, $\mathrm{CO}_{2}$ produced from Equation 1 reacts with calcium hydroxide $\left(\mathrm{Ca}(\mathrm{OH})_{2}\right)$ present in large quantities in concrete as a product of cement hydration to precipitate additional $\mathrm{CaCO}_{3}$. Similarly, Equation 3 shows that calcium acetate $\left(\mathrm{Ca}\left(\mathrm{C}_{4} \mathrm{H}_{6} \mathrm{O}_{4}\right)\right)$ oxidates into $\mathrm{CaCO}_{3}, \mathrm{H}_{2} \mathrm{O}$ and $\mathrm{CO}_{2}$, with the latter undergoing the same reaction with $\left(\mathrm{Ca}(\mathrm{OH})_{2}\right)$ as seen in Equation 4. It has been noted that MICP through oxidation of organic compounds occurs primarily with bacteria of the genera Bacillus pseudofirmus, Bacillus cohnii, Bacillus alkalinitrilicus and Bacillus sp., which may be further complemented with other MICP-inducing metabolic processes [31].

As noted in Equation 1 and Equation 3, calcic nutrients are needed for the bacteria to perform MICP. Most studies make use of calcium lactate [10], [15], [27], [33], [35]-[37] calcium nitrate [25], [38], [39] calcium chloride [40], [41] and calcium acetate [33], [40], [42]. In addition to calcic nutrients, other more complex nutrients have been used such as yeast extract [15], [25], [33], [38], [39], [43], [44], meat extract [45] and peptone [33], [45]. However, these nutrients are known to have lower efficiency since their exact composition is unknown, especially with respect to calcium content [31]. The effect of different nutrients on strength resistance has been tested in cement pastes aged over time [33]. Results demonstrated that calcium lactate yielded the best results, with a strength increase comparing with control samples.

Studies conducted in Brazil have obtained positive results of MICP with Bacillus subtilis AP91 [46]. Surface treatment of pre-existing concretes has also been performed with Bacillus sphaericus and resulted in water absorption, gas permeability and chromatic aspect values similar to the application of commercial hydrophobic additives [40]. 
Surface treatment also reduced water absorption with beneficial effects on concrete durability [47]. Visual investigation of healed fissures confirmed the great potential of this technique with healing of fissures as wide as $0.79 \mathrm{~mm}$ [15]. Testing variations in general, each with distinct concentrations, led to an overall increase in strength resistance of cementitious compounds [45], [30]. Bacillus, Sporosarcina and Shewanella genera were tested in concentrations varying from $5 \times 10^{4}$ cells $/ \mathrm{mL}$ to $2.8 \times 10^{8}$ cells $/ \mathrm{mL}$ and a concentration of $3 \times 10^{6}$ measured in colony-forming units $/ \mathrm{mL}(\mathrm{CFU} / \mathrm{mL})$.

Bacterial solution used in substitution to mixing water resulted in an increase of $13 \%$ in strength resistance and $8.5 \%$ reduction in permeability [47]. However, bacteria may be damaged over time, cause its metabolic activity decreases in environments with $\mathrm{pH}$ above 12 [43]. In extreme cases, bacteria may not survive the alkaline environment, mechanical stresses of concrete mixing or cement hydration since matrix pores have dimensions of less than $0.5 \mu \mathrm{m}$ while bacteria have dimensions between $1 \mu \mathrm{m}$ and $3 \mu \mathrm{m}$ [10], [25], [33], [36]. Consequently, micro-organisms encapsuled in light or porous aggregates have been tested [15], [27], [34]. Fissuring ruptures the capsules and releases the healing agent, which seeps into the matrix though capillary penetration [48].

Bacteria of the specie B. cohnii were tested encapsulated in expanded clay (EC) and expanded perlite (EP) in the 2 $\mathrm{mm}$ to $4 \mathrm{~mm}$ granulometric range [15] and found healing to be more effective with EP. A bacterial solution of $B$. pseudofirmus DSM 8715 encapsulated in EP was successfully used in $20 \%$ substitution by volume of sand in concrete [34]. In order to prevent premature release of the healing agent, higher resistance coatings are recommended for the capsules in order to ensure light aggregate integrity during the mixing process [48]. Some types of coatings commonly used are geopolymers [15] and cement [49]. As for the effects of curing, self-healing mortars were tested in submerged curing and wet/dry cycles [37]. It was determined that the underwater cure form ef euring yielded better results, probably due to the higher availability of oxygen.

Despite the use of coatings and the use of capsules for bacterial solutions, as mentioned before, it is also noted that studies evaluated the bacterial solution concentration, considering its relevance in the process of healing. Vijay, Murmu and Deo [30], for example, presented several studies with the authors choice for the bacterial concentration. Sidiq, Gravina and Giustozzi [50], considering specifically the specie $B$. subtilis pointed out the use of $10^{5} \mathrm{cell} / \mathrm{ml}$. It is noted that the concentration must be selected for each specie, considering the characteristics of the microorganisms.

This study conducted mechanical and visual analyses of mortars with the addition of B. subtilis AP91 solutions in $\mathrm{CFU} / \mathrm{mL}$ concentrations of $3 \times 10^{6}, 3 \times 10^{7}$ and $3 \times 10^{8}$ encapsulated in EP, aiming to analyze if this concentration has effect on mechanical performance of the samples and its potential to promote self-healing. The encapsulating potential of the EP aggregate was also evaluated through void space measurements in a scanning electronic microscope (SEM) and the EP distribution in the mortar matrix was evaluated with micro-computed tomography $(\mu \mathrm{CT})$.

EP capsules were chosen among other options due to their availability in the study region, and for their compatibility with concrete matrix in self-healing concretes [15]. Other systems can be used, such as superabsorbent polymers [51] or vascular networks however [52], with complex preparation procedures.

Several research have been carried out in the study of self-healing of cementitious materials, however, when it comes to self-healing promoted by biological agents, little is discussed about the influence of the concentration of these agents in this process. Still, there is a lack of published studies using microorganisms cataloged in Brazil. It is hoped that this study will contribute to the development of self-healing Brazilian cementitious materials, as well as bringing to discussion not only the different varieties of microorganisms used to promote self-healing, but also the concentration in which they are inserted in matrices.

\section{EXPERIMENTAL PROCEDURES}

\subsection{Mixing ratio and characterization of materials}

The bacteria used in this study was the same as Schwantes-Cezario, Nogueira and Toralles [53] and SchwantesCezario et al. [54]. Consequently, the same mixing ratio of 1:1 (cement: sand) in mass was used in the mortar. Expanded perlite (EP) with grain sizes between $2.4 \mathrm{~mm}$ and $4.8 \mathrm{~mm}$ was used to encapsulate the micro-organisms as in Zhang et al. [15]. It should be noted that granulometry of the EP used in Zhang et al. [15] yielded sizes between $2 \mathrm{~mm}$ to $4 \mathrm{~mm}$. Since the sieve sizes were defined according to ASTM C33 [55], an adaptation to the diameters was necessary for this study. Fine EP aggregate was used in a substitution of $30 \%$ in volume for sand so that the final adapted mixing ratio was defined as 1:0.7:0.084 (cement: sand: EP). While the amount of EP substitute remained constant, the concentrations of bacterial solution varied throughout this study. Table 1 presents the mixing ratio of materials for each sample with respect to a $1 \mathrm{~kg}$ consumption of cement. 
Table 1 - Materials and mixing ratio of samples studied

\begin{tabular}{cccccc}
\hline Sample & Cement, kg & Sand, kg & EP, kg & $\begin{array}{c}\text { B. subtilis AP91 concentration, } \\
\text { UFC/ml }\end{array}$ & Water/cement ratio \\
\hline BAC.6 & 1 & 0.7 & 0.084 & $3 \times 10^{6}$ & 0.37 \\
\hline BAC.7 & 1 & 0.7 & 0.084 & $3 \times 10^{7}$ & 0.37 \\
\hline BAC.8 & 1 & 0.7 & 0.084 & $3 \times 10^{8}$ & 0.37 \\
\hline
\end{tabular}

Cement used was of Type IL(10) as defined in ASTM C595 [56] with no pozzolanic addition. Laser granulometry, surface area and density tests were conducted on the cement. Laser granulometry was performed in a Microtrac model S3500 apparatus with isopropyl alcohol as fluid. Surface area tests were conducted with Brunauer, Emmett and Taller (BET) isotherms and MicroActive TriStar II Plus 2.02 software. Density was measured in a helium gas pycnometer following ASTM D5550 [57] procedures. Results were a surface area of $2.0474 \pm 0.0085 \mathrm{~m}^{2} / \mathrm{g}$ and density of $3.0049 \mathrm{~g} / \mathrm{cm}^{3}$, while granulometry results are presented in Figure 1. Sand granulometry was obtained with ASTM C33 [55] and density was obtained with ASTM C128 [58] and ASTM C29 [59]. The sand used was quartzbased and locally sourced from a river. Similar procedures were followed to obtain EP granulometry and apparent density. The apparent density of EP was measured for the natural original as well as the bacterial solution-impregnated and coated materials. Sand and EP characterizations are shown in Table 2 while granulometries are shown in Figure 2.

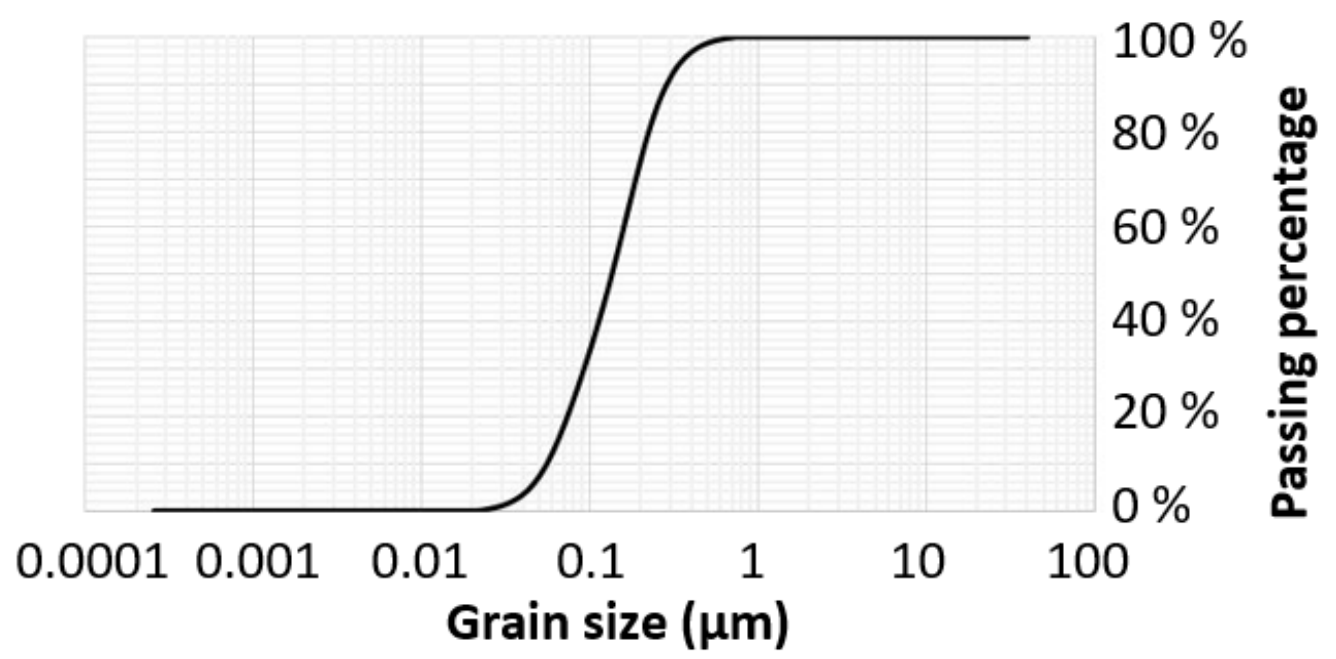

Figure 1 - Cement particle size distribution.

Table 2 - Density and apparent density of aggregates

\begin{tabular}{cccccc}
\hline Aggregate & $\begin{array}{c}\text { Apparent Density } \\
\mathbf{k g} / \mathbf{m}^{\mathbf{3}}\end{array}$ & $\begin{array}{c}\text { Density } \\
\mathbf{k g} / \mathbf{m}^{\mathbf{3}}\end{array}$ & $\begin{array}{c}\text { Maximum characteristic dimension, } \\
\mathbf{m m}\end{array}$ & $\begin{array}{c}\text { Fineness } \\
\text { modulus }\end{array}$ \\
\hline \multirow{2}{*}{ EP } & Sand & $1,734.33$ & 2,700 & 3.26 & 3.01 \\
\cline { 2 - 4 } & Natural & 94.36 & - & 4.75 & 4.14 \\
\hline
\end{tabular}




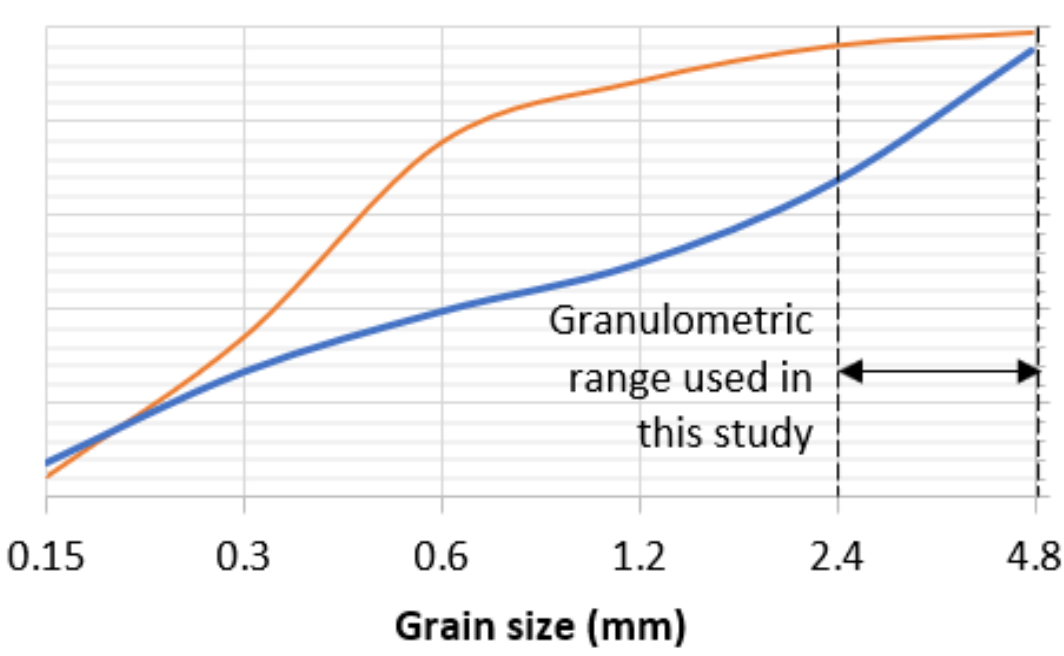

Figure 2 - Aggregate granulometry

\section{$100 \%$}

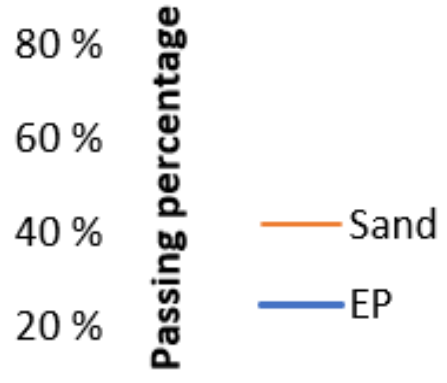

It should be noted that despite sand not having the same granulometric distribution, a limited EP granulometric range was used in this study. This was defined in order to match sizes used in other studies [15], [27], and to allow direct comparison of the results between them. The chemical composition of EP is shown in Table 3, according to data provided by the producer.

Table 3 - Chemical composition of EP

\begin{tabular}{cccccccccccc}
\hline \multicolumn{2}{c}{$\mathbf{S i O}_{2}$} & \multicolumn{2}{c}{$\mathbf{A l}_{\mathbf{2}} \mathbf{O}_{\mathbf{3}}$} & \multicolumn{2}{c}{$\mathbf{F e}_{\mathbf{2}} \mathbf{O}_{\mathbf{3}}$} & \multicolumn{2}{c}{$\mathbf{T i O}_{\mathbf{2}}$} & \multicolumn{2}{c}{$\mathbf{C a O}$} & \multicolumn{2}{c}{$\mathbf{M g O}$} \\
\hline Min & Max & Min & Max & Min & Max & Min & Max & Min & Max & Min & Max \\
\hline 71 & 78 & 8.5 & 15 & 0.3 & 1.2 & 0.01 & 0.01 & 0.3 & 1.2 & 0.1 \\
\hline \multicolumn{2}{c}{$\mathbf{N a}_{2} \mathbf{O}$} & \multicolumn{2}{c}{$\mathbf{K}_{\mathbf{2}} \mathbf{O}$} & \multicolumn{2}{c}{$\mathbf{S O}_{3}$} & \multicolumn{2}{c}{$\mathbf{P}_{2} \mathbf{O}_{\mathbf{5}}$} & \multicolumn{2}{c}{$\mathbf{M n O}$} & Loss of Ignition \\
\hline Min & Max & Min & Max & Min & Max & Min & Max & Min & Max & Min & Max \\
\hline 2.5 & 4.2 & 3.00 & 7.00 & 0.01 & 0.01 & 0.01 & 0.03 & 0.01 & 0.04 & 0.10 & 2.00 \\
\hline
\end{tabular}

\subsection{Growth curve, cultivation and bacterial encapsulation}

The B. subtilis AP91 strain used was provided by the Campinas branch of Empresa Brasileira de Pesquisa Agropecuária - EMBRAPA. Cultivation in vitro was conducted in Luria Bertani (LB) broth containing $10 \mathrm{~g} / \mathrm{L}$ of tryptone $5 \mathrm{~g} / \mathrm{L}$ of yeast extract and $5 \mathrm{~g} / \mathrm{L}$ sodium chloride in deionized water. This broth has been used to adequately cultivate $B$. subtilis [48], [53]. A volume of $100 \mathrm{~mL}$ of LB broth was placed in two $250 \mathrm{~mL}$ Erlenmeyers flasks each and sterilized in an autoclave at $121^{\circ} \mathrm{C}$ for $15 \mathrm{~min}$. Following sterilization, each flask was inoculated, and the cultures were incubated in an orbital shaker at $165 \mathrm{rpm}$ and $37^{\circ} \mathrm{C}\left(98.6^{\circ} \mathrm{F}\right)$ for $24 \mathrm{~h}$. The growth curve was obtained by taking samples over the incubation period. The cultivation absorbance was analyzed in a Kazuaki model IL-226-NM spectrophotometer of $600 \mathrm{~nm}$ wavelength. Simultaneously to the absorption measurement, each sample was ten-fold serially diluted in saline solution ( $0.9 \%$ sodium chloride) and each dilution was pour-plated in agar LB for colony forming unit (CFU) counting. It should be noted that not all bacteria exist as isolated cells and bacterial agglomerates and groups also generate a single colony. Due to this fact, colony-counting cannot be taken as the absolute number of cells and, thus, CFU was selected [60]. Plated samples were placed in an incubator at $36^{\circ} \mathrm{C}$ for $48 \mathrm{~h}$, at which point colonies were counted for the corresponding absorption value. The procedure adopted is shown in Figure 3 and described in detail in Swanson et al. [60]. Figure 4 shows the species spectrophotometric behavior relating the absorbance and concentration of each sample. 

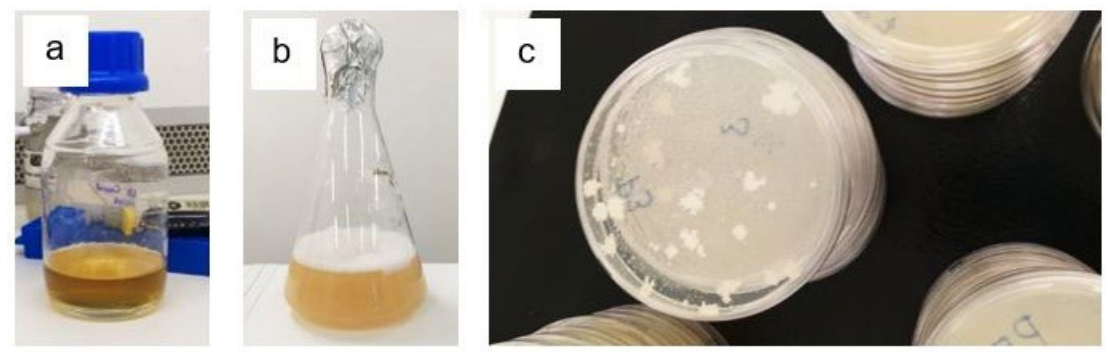

Figure 3 - Procedures for spectrophotometry of $B$. subtilis AP91: (a) sterile LB Broth, (b) LB broth with bacterial growth and (c) colonies $48 \mathrm{~h}$ after in an incubator

The figure allows the determination of the cultivation level of $B$. subtilis AP91 based on its absorbance. In the equation, shown overlaid in Figure 4, the absorbance $\left(\mathrm{A}_{600}\right)$ is dimensionless and concentration $(\mathrm{C})$ is given in $\mathrm{CFU} / \mathrm{mL}$. The figure allows the determination of the cultivation level of B. subtilis AP91 based on its absorbance. In the equation, shown overlaid in Figure 4, the absorbance $\left(\mathrm{A}_{600}\right)$ is dimensionless and concentration $(\mathrm{C})$ is given in $\mathrm{CFU} / \mathrm{mL}$.

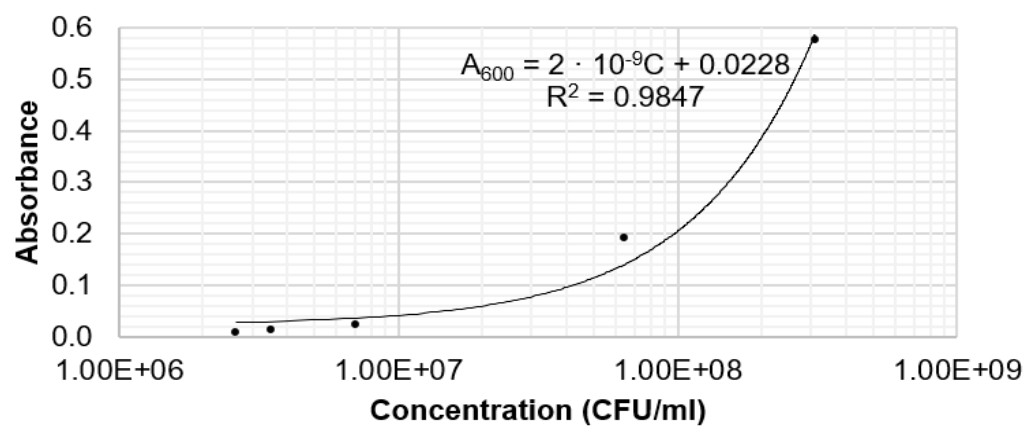

- Laboratory measurements Calculated model

Figure 4 - Spectrophotometric behavior of B. subtilis AP91

A sterile buffer solution containing $1.06 \mathrm{~g} / \mathrm{L}$ of sodium phosphate (anhydrous dibasic), $0.36 \mathrm{~g} / \mathrm{L}$ sodium phosphate (monobasic) and $8.17 \mathrm{~g} / \mathrm{L}$ sodium chloride in deionized water was used as dilutant for the bacteria for the purpose of encapsulation and later insertion in the cementitious mixture. In parallel, the bacteria were inoculated in $2 \mathrm{~L}$ Erlenmayer flasks with $1 \mathrm{~L}$ of sterile BL broth and incubated in an orbital shaker for $24 \mathrm{~h}$. Following the $24 \mathrm{~h}$ growth period, the solutions were centrifuged in an Eppendorf AG model $5430 \mathrm{R}$ centrifuge at $4,000 \mathrm{rpm}$ and $23^{\circ} \mathrm{C}$ for $3 \mathrm{~min}$ to precipitate the cells. The supernatant was discarded, and the cells washed 4 more times with the sterile phosphate buffer solution, each time following the same previous centrifugation and supernatant discarding procedures. This was done in order to remove any organic matter present in the cultivation solution. The progressive changes in visual appearance of the solution are shown in Figure 5. The buffer solution and washing procedures followed the methodology of SchwantesCezario et al. [53].



Figure 5 - LB broth (a) before (b) and after centrifugation; (c) buffer solution before (d) and after centrifugation 
After washing, cells were re-suspended in phosphate buffer solution and its absorbance was measured to define the initial concentration. Then, the solution was diluted to the target concentration. The solutions were refrigerated at $8{ }^{\circ} \mathrm{C}$ for 2 days in order to promote sporulation [53] and slows down cellular multiplication [29], ensuring that concentrations are kept constant.

Impregnation of EP with bacterial solution was accomplished by submerging the aggregate for 3 hours in different concentration solutions. After soaking, the EP was placed in a vacuum desiccator for the 30 min necessary to achieve maximum impregnation [49]. Following impregnation, excessive liquid was drained, and EP dried in an incubator at $45^{\circ} \mathrm{C}$ for $48 \mathrm{~h}$. After drying, EP was sprayed with a calcium lactate solution containing $8 \mathrm{~g} / \mathrm{L}$ of calcium lactate, $1 \mathrm{~g} / \mathrm{L}$ of yeast extract and deionized water and further incubated at $45^{\circ} \mathrm{C}$ for $48 \mathrm{~h}$ - This procedure followed the methodology of Zhang et al. [15]. As a protective coating, the same cement used in the mortar was sprinkled on the aggregate following the procedure of Sisomphon et al. [49]. Although not mentioned in other studies, a further spraying of the calcium lactate solution prior to coating with cement was necessary to promote hydration and improve adhesiveness. Once the encapsulation process was completed, the aggregate was kept at rest for 7 days to cure the cement coating prior to molding the test samples as per the methodology of Zhang et al. [15].

\subsection{Molding of samples}

Cylindrical (50 mm x $100 \mathrm{~mm}$ or 1.96in x 3.93in) and prismatic $(40 \mathrm{~mm}$ x $40 \mathrm{~mm} \times 160 \mathrm{~mm})$ samples were molded and cured in a climate-controlled chamber (humidity and temperature) for 7 days [61]. Fissures were induced in prismatic samples with a bending test following ASTM C348 [62]. To prevent total sample rupture, a $5 \mathrm{~mm}$ diameter CA 60 steel bar was inserted $1 / 4$ into the base of the samples in a similar procedure as Alghamri et al. [63]. After fissuring, samples were returned to the chamber to promote oxygenation to the bacteria and induce the biomineralization reaction.

\subsection{Visual analysis of healing, capillary absorption of water and strength resistance tests}

After fissuring, visual analyses were conducted at 7, 14, 28 and 42 days to inspect for signs of healing and monitor its evolution. A Motic SMZ-168 stereo zoom microscope was used for inspection and measurements were taken with AutoCAD ${ }^{\mathrm{TM}}$ software. A capillary absorption test was conducted at 42 days following the procedure of RILEM TC 116-PCD [64] to obtain the mass of absorbed water relative to exposed area. The sample was leached with hydrochloric acid to remove any calcium carbonate precipitation and return the samples to their pre-healing state. The absorptivity test was then repeated, and the results allowed comparison of absorption pre and post-healing. Strength resistance tests were conducted following ASTM C39 [65] procedures at 7 days, 28 days and 54 days after demolding.

\subsection{Complementary analyses}

Scanning electronic microscopy (SEM) with a Zeiss brand apparatus was used in EP samples embedded in the cementitious matrix in order to determine their internal microstructure and suitability as capsule for $B$. subtilis. Along with SEM, an energy dispersion spectroscopy (EDS) was performed to evaluate EP chemical composition before and after calcium lactate spraying in order to determine its effective presence on the surface of the structure. Since EP is extremely porous, density variations allowed micro-computed tomography $(\mu \mathrm{CT})$ to determine its distribution in the cementitious matrix. For these complementary analyses, fragments of sample BAC.7 were used from which planes were sliced with a circular saw. Exceptionally, pre-spraying samples of EP were taken for EDS analysis from the natural aggregate as supplied by the manufacturer. The samples were dried at $50^{\circ} \mathrm{C}$ until mass constant and then metallized with gold.

\section{RESULTS AND DISCUSSION}

\subsection{Compressive strength and capillary absorption of water}

Figure 6 demonstrates that the average strength resistance remained at around the same level for the samples over the time periods of this study. 


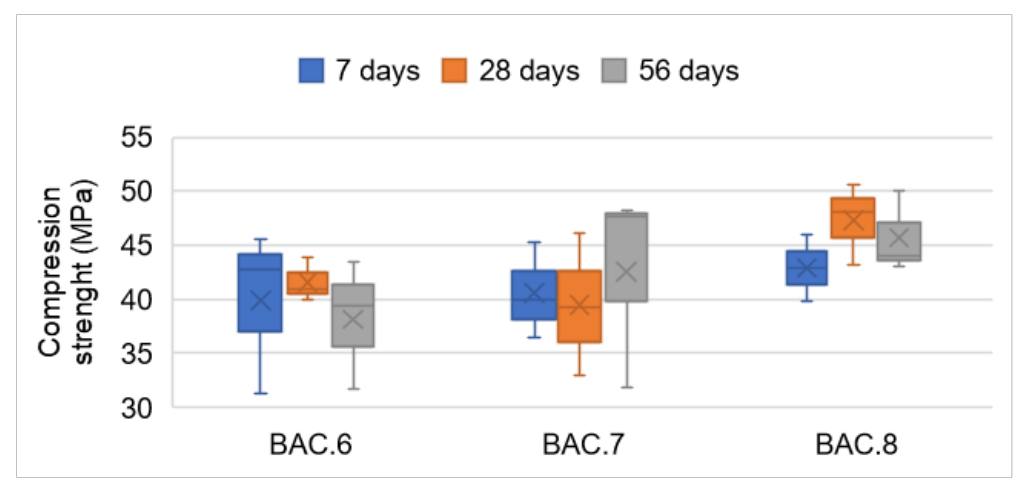

Figure 6 - Compression resistance results at 7 days, 28 days and 56 days

The largest variation was measured at $4.4 \mathrm{MPa}$, or $10.26 \%$ with respect to the smallest value, for sample BAC. 8 between 7 days and 28 days. The fact that there was little variance from 7 days to 56 days could be attributed to the type of cement used, which contained an elevated percentage of clinker [56] and resulted in considerable strength from an early age. The largest difference in strength between mixing ratios for the same period was measured between BAC. 7 and BAC. 8 at 28 days: $7.9 \mathrm{MPa}$, or $20 \%$ with respect to the smallest value. The relatively low variance in strength between mixing ratios could be attributed to the identical cement: sand: EP ratio and water/cement relation between samples, of which only bacterial concentration varied. These results indicated that bacterial addition had no impact in the uncracked specimens despite the possibility of naturally occurring micro-fissures being formed in the cementitious matrices. Even if these micro-fissures were present, they were likely in small quantities and size since the samples themselves were of small size and have a high degree of freedom, thus minimizing fissuring from retractions.

Comparisons with Schwantes-Cezario et al. [53], which provided the mixing ratio, denoted that there was a decrease in strength. While strengths for the samples of this study were measured in the approximate range of $35 \mathrm{MPa}$ to $50 \mathrm{MPa}$, SchwantesCezario et al. [53] obtained strengths in the range of $55 \mathrm{MPa}$ to $75 \mathrm{MPa}$. This decrease was likely due to inserted EP being a lighter aggregate in the cementitious matrix as noted by Jonkers [35]. On the other hand, Afifudin et al. [24] observed that the same mixing ratio but with $B$. subtilis inserted directly in the matrix in different concentrations yielded more significant differences. It should be noticed that the authors did not use capsules, and thus, the bacterial solution may have contributed with the formation of the crystals along the sample, achieving better strength results.

The low variation in strength due to concentration observed in the samples of this study were likely the result of EP preventing bacterial activity in the uncracked samples. This was in agreement with the expectation that healing agents would only become active after the capsules were ruptured [63], [66].

Figure 7 shows the average water absorption of all samples before and after leaching with hydrochloric acid. It should be noted that it was not possible to compare absorption between samples because the fissures did not have the same geometry. At the $24 \mathrm{~h}$ mark, it could be seen that all samples had higher absorption after leaching with increases of $18.76 \%, 8.62 \%$ and $43.45 \%$ for samples BAC.6, BAC.7 and BAC.8, respectively. Although there was no proportional relationship between bacterial concentration and decrease in absorption, it could be stated that BAC.8 presented a higher efficiency in healing.

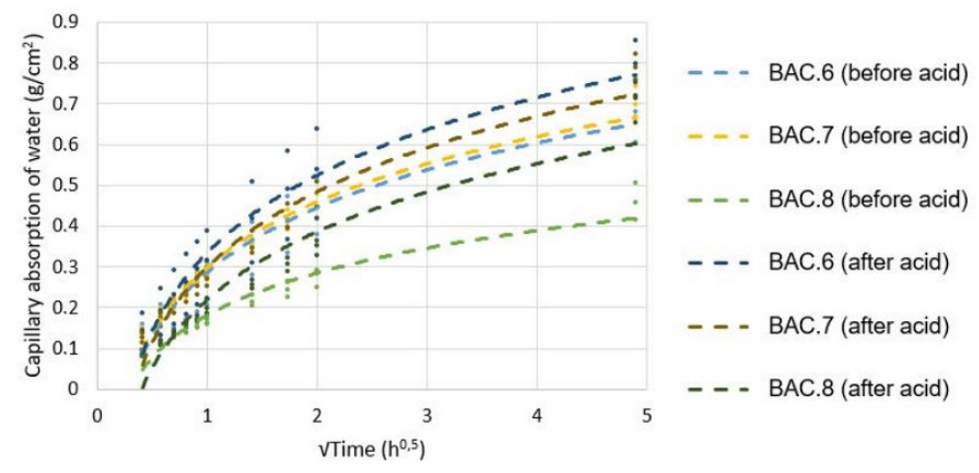

Figure 7 - Average absorptivity of all samples before and after acid leaching 
Results obtained in this study, especially with BAC.8, were in-line with Alghamri et al. [63], which obtained a decrease of about $50 \%$ in absorption with a sodium silicate solution encapsulated when compared to control samples. Additionally, Siddique et al. $\{62\}$ [67] inserted a bacterial solution in the matrix with no encapsulation and obtained absorption reductions between $50 \%$ and $70 \%$. In this case, the direct insertion of bacteria had a more efficient impact in absorption since their action was not conditioned to capsule rupturing.

\subsection{Visual surface analysis, SEM analysis and Micro-computed tomography}

A total of 9 samples were molded for visual analysis and all presented evidence of at least 1 or more surface healing locations.

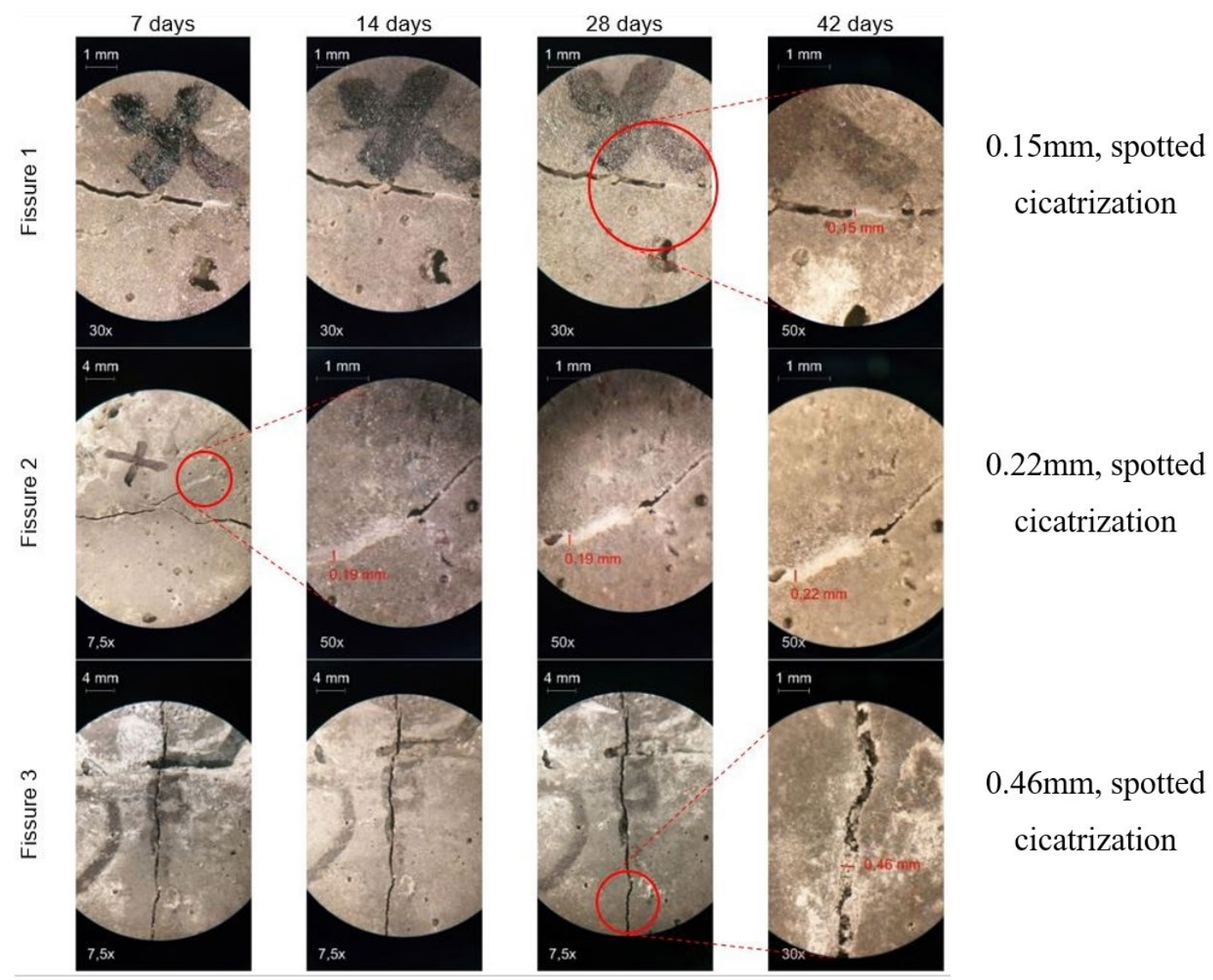

Figure 8 - Self-healing activity of sample BAC.6 at several ages

Figure 8 shows the results for sample BAC.6 at several ages, designated fissure 1 through 3 . In Figure 8, fissures 1 and 2 were healed at 7 days and no further major healing products were formed at older ages. However, fissure 3 presented a different coloration healing which healed further between 28 days and 42 days. For sample BAC.6, the maximum healing width was of $0.46 \mathrm{~mm}$ and healing occurred in spots rather than along the extent of the fissure. Spotted healing similar to fissure 1 and fissure 2 was also observed in others studies [63ł [68]. Wall-bound healing presented in fissure 3, which could further evolve and result in complete healing at later ages, was also annotated by Khaliq and Ehsan [69]. Whether spotted or wall-bound, healing could be attributed to the local availability of EP releasing products for self-healing. It should be noted that, regardless of the type of healing, the visual aspect observed in the samples were of a whitish product, referred to in other works as calcite formed from bacterial solutions [21], [70]. Figure 9 shows the results from sample BAC.7, designated fissure 4 through 7. 


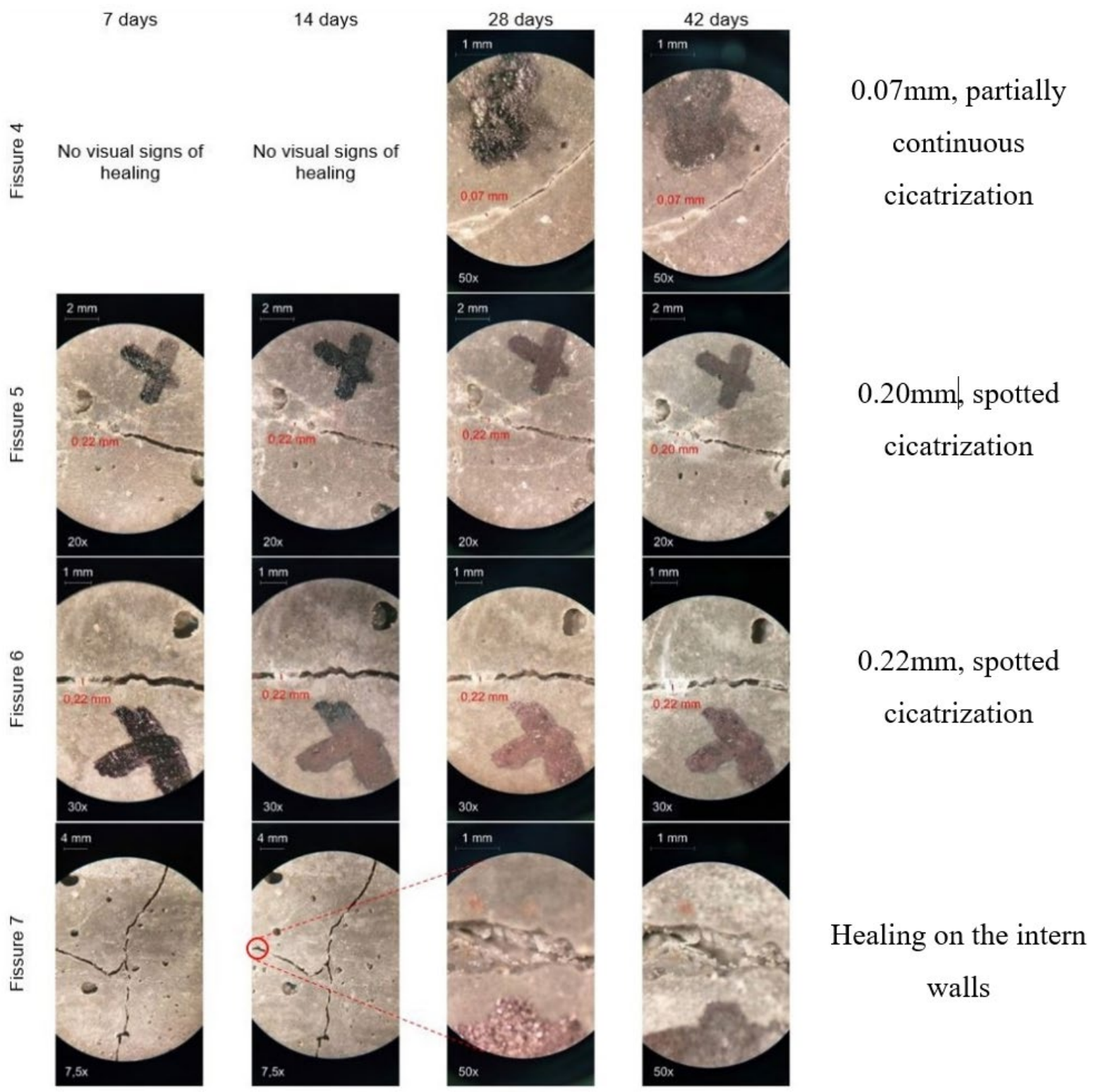

Figure 9 - Self-healing activity of sample BAC.7 at several ages

Fissure 4 did not present evidence of healing at 7 days and 14 days so there are no images associated with these ages. The healing in sample BAC.7 occurred in a similar fashion to sample BAC.6: namely, there were observable appearances of products in the fissures but, after a certain age, no further healing evolution. Figure 10 shows the results from sample BAC.8, designated fissure 8 through 11. 

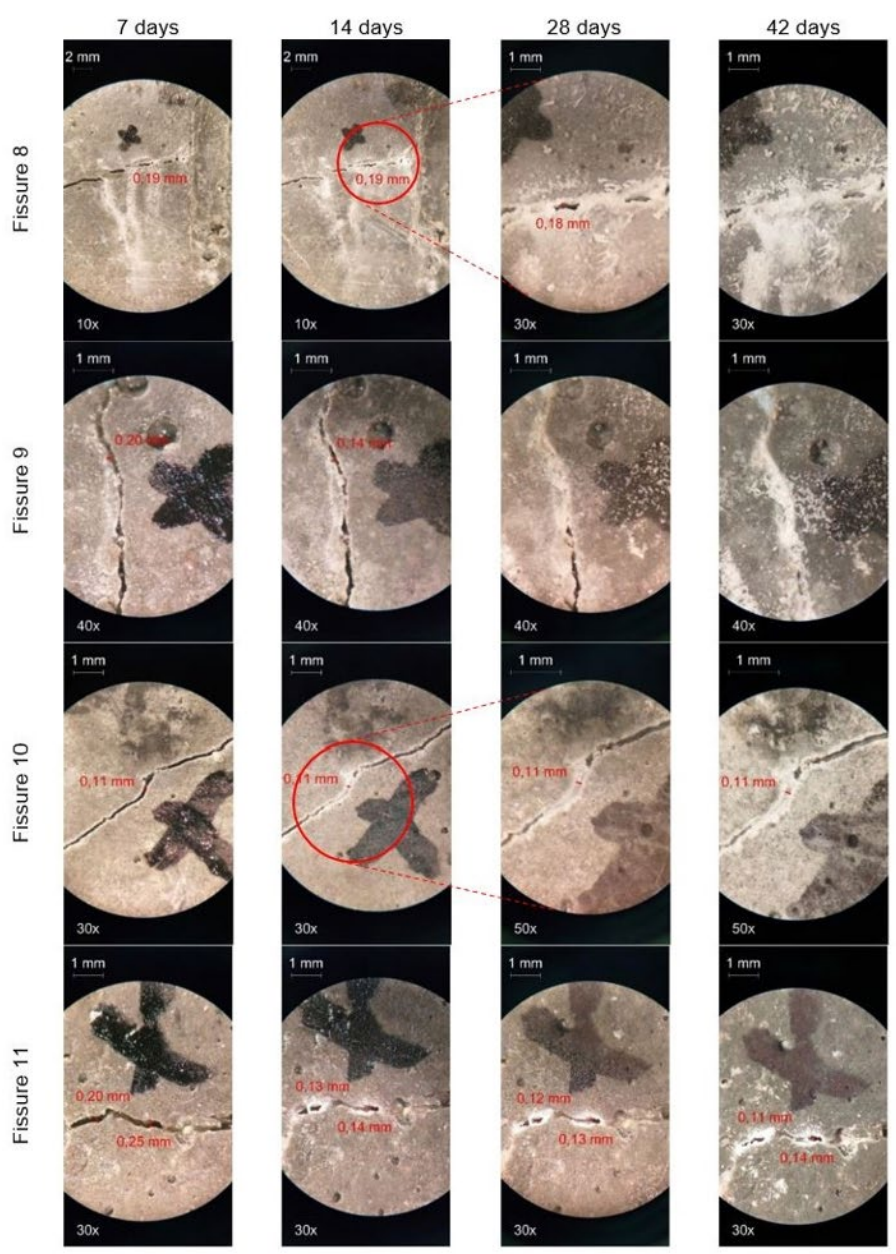

\section{$0.18 \mathrm{~mm}$, partially}

continuous

cicatrization

$0.20 \mathrm{~mm}$, continuous

cicatrization

\section{$0.11 \mathrm{~mm}$, spotted \\ cicatrization}

\section{$0.11 \mathrm{~mm}$, spotted \\ cicatrization and}

healing on the intern

walls

Figure 10 - Self-healing activity of sample BAC.8 at several ages

Unlike previous samples, BAC.8 presented an expressive healing evolution from 7 days to 42 days. Similar evolutions were observed in other studies [15], [27]. Healing was also observed to appear along the entire length of the fissure, which made the BAC.8 sample the most efficient of the samples tested in this study, with a maximum width of fissure healed of $0.20 \mathrm{~mm}$. It should also be noted that not only concentrations of healing product were detected in the fissure but further calcite deposits were observed on the surface - a behavior observed by Zhang et al. [15]. Table 4 presents the results of the visual analysis.

Table 4 - Synthesis of visual analysis results

\begin{tabular}{cccc}
\hline Sample & Fissure & Maximum healed width, mm & Type of healing \\
\hline \multirow{3}{*}{ BAC.6 } & 1 & 0.15 & Spotted \\
& 2 & 0.22 & Spotted \\
& 3 & 0.46 & Spotted \\
& 4 & 0.07 & Partially continuous \\
\cline { 2 - 4 } BAC.7 & 5 & 0.22 & Spotted \\
& 6 & 0.22 & Spotted \\
\hline & 7 & 0.00 & Starting healing on the walls \\
& 8 & 0.19 & Partially continuous \\
\hline & 9 & 0.20 & Continuous \\
\hline & 10 & 0.11 & Spotted \\
\hline
\end{tabular}

${ }^{*}$ There was no total closure of the fissure width. The reported value is the difference between the initial and final widths. 
The maximum fissure width healed was $0.46 \mathrm{~mm}$ for BAC.6, which was an exceptional value with respect to the other samples. The remaining samples had maximum healed fissure widths between $0.20 \mathrm{~mm}$ and $0.22 \mathrm{~mm}$ regardless of the composition. Comparing the results of this study with reference works, encapsulated in EP and coated in cement obtained a maximum healing width of $0.4 \mathrm{~mm} \mathrm{~B}$. cohnii but most healed fissures were below $0.3 \mathrm{~mm}$ [27]. Similarly, B. cohnii encapsulated in EP but coated in geopolymer obtained a maximum healing width of $0.8 \mathrm{~mm}$ while also presenting higher efficiency for fissures up to $0.3 \mathrm{~mm}$ in width [15]. The differences observed between the studies may be related to the genus of bacteria or the type of coating. In the case of Jiang et al. [27], an alternative coating of magnesium potassium phosphate cement was able to heal a fissure $1.24 \mathrm{~mm}$ wide.

Besides differences in composition between samples, an aspect of extreme importance for healing to occur was the EP distribution inside the matrix. Accordingly, visual analysis of this study did not indicate a relation between the aspect of the fissure and the type of healing, further reinforcing that aggregate dispersion may be the single most relevant factor. This consideration was also postulated in De Koster et al. [71]. Scanning electronic microscopy (SEM) was used to obtain the EP and micro-structure shown in Figure 11.

(a)

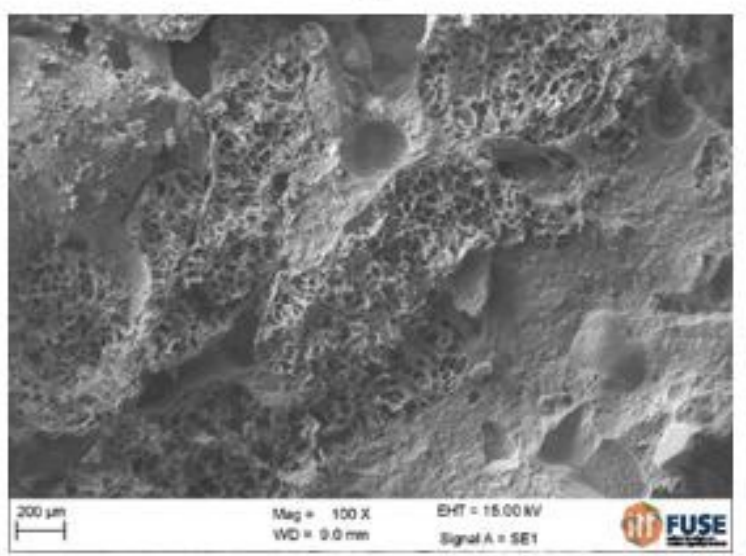

(b)

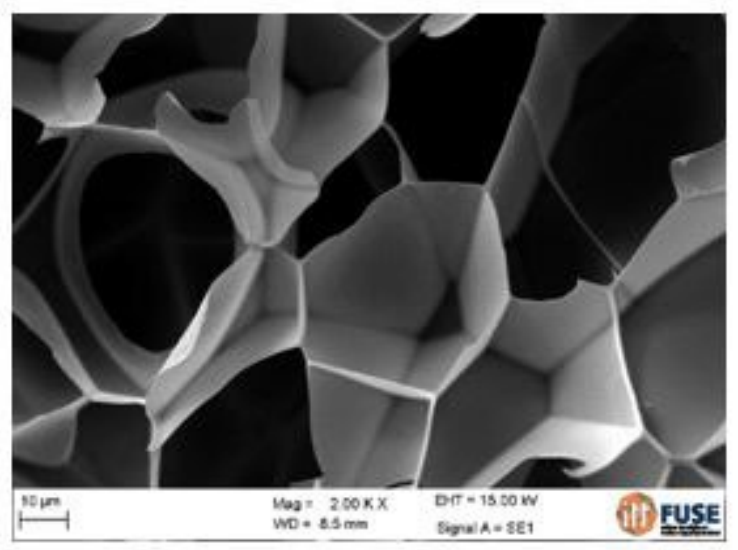

Figure 11 - SEM of a slice of EP at magnifications of (a) 100x and (b) 2,000x

It could be observed that a great quantity of void spaces was present inside the aggregate, in opposite contrast to a compact cementitious matrix. Pores were measured to have dimensions in the order of $10 \mu \mathrm{m}$ to $40 \mu \mathrm{m}$. Since $B$. subtilis AP91 spores had known approximate diameters of $1 \mu \mathrm{m}$ [35] this demonstrated that the aggregate had sufficient space for encapsulation. However, bacterial spores were not seen inside EP in Figure 11. This could be explained as: (a) the EP cut used for SEM was too far from the surface of the aggregate at a depth at which bacteria might not have been absorbed (b) sample preparation required cutting and water from the cutting disk inevitably reached the test sample and may washing away of the micro-organisms from the EP.

Scanning electronic microscopy of EP impregnated with B. cohnii was also conducted by Jiang et al. [27] and bacterial spore were observed. Spore distribution, however, was not homogeneous within the aggregate. This result highlighted the need of more studies to determine the total bacterial impregnation effectiveness. Otherwise, bacteria would be limited to void spaces located around the external part of the aggregate with considerable impact on the chosen EP granulometry to be used. To this end, an energy dispersion spectroscopy (EDS) was performed in the samples of this study before and after spraying of calcium lactate. Results are shown in Figures 12a and $12 \mathrm{~b}$ and the percentage of elements detected is shown in Table 5. 

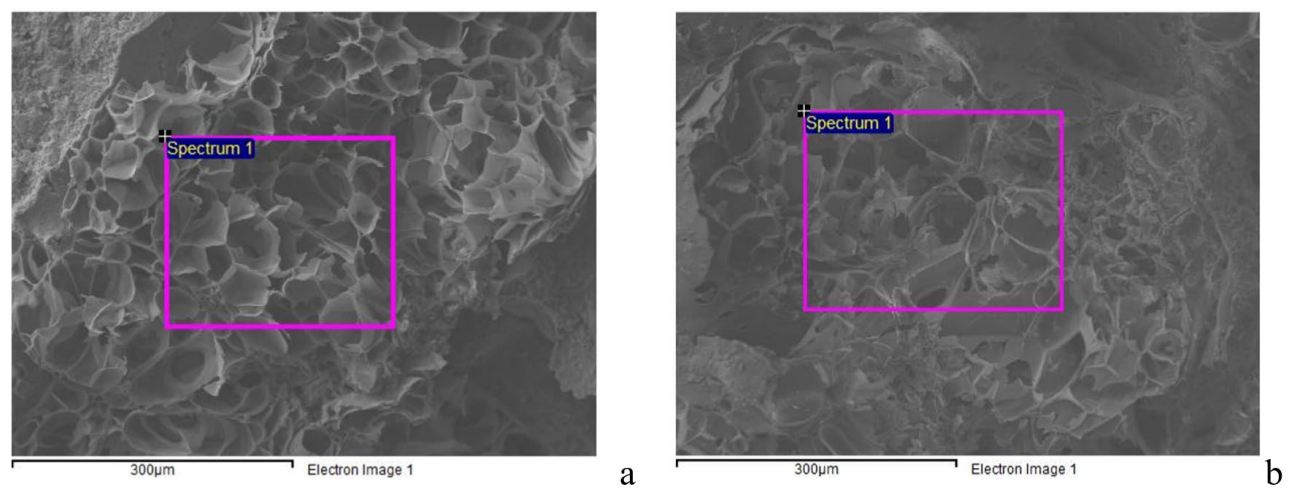

Figure 12 - Target region analysed (a) EP capsule in mortar for EDS analysis (b) EP grain without impregnation with bacterial solution or coating for EDS analysis

Table 5 - Percentage of elements found through EDS in the samples

\begin{tabular}{|c|c|c|c|c|}
\hline \multirow{2}{*}{ Element } & \multicolumn{2}{|c|}{ EP with calcium lactate, $\%$} & \multicolumn{2}{|c|}{ EP without bacterial solution or coating, \% } \\
\hline & Weight & Atomic & Weight & Atomic \\
\hline $\mathrm{O}$ & 41.91 & 57.85 & 43.05 & 57.65 \\
\hline $\mathrm{Na}$ & 1.96 & 1.88 & 2.27 & 2.12 \\
\hline $\mathrm{Al}$ & 5.79 & 4.74 & 7.18 & 5.70 \\
\hline $\mathrm{Si}$ & 33.41 & 26.27 & 40.70 & 31.04 \\
\hline $\mathrm{K}$ & 8.57 & 4.84 & 4.76 & 2.61 \\
\hline $\mathrm{Ca}$ & 7.09 & 3.91 & 0.62 & 0.33 \\
\hline $\mathrm{Fe}$ & 1.26 & 0.50 & 1.41 & 0.54 \\
\hline Total & 100.00 & & 100.00 & \\
\hline
\end{tabular}

Table 5 allows a chemical comparison between samples. It was clear that the EP sample sprayed with calcium lactate yielded a percentage of calcium 11x higher in its composition compared with the untreated EP grain. This indicated a successful absorption of the bacterial solution in the light aggregate.

Figure 13 displays images from micro-computed tomography $(\mu \mathrm{CT})$ at the sample.
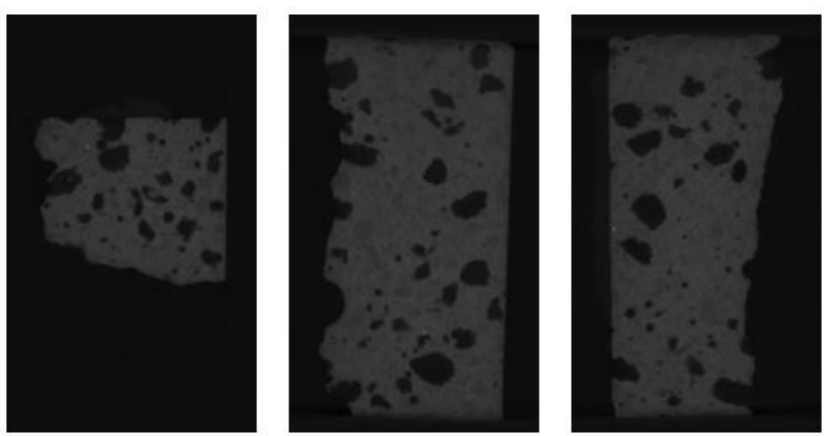

Figure $13-\mu \mathrm{CT}$ images of all 3 planes of a sample

It could be seen that EP distribution inside the cementitious matrix was fairly homogeneous. Despite the differences in mass percentage of each material, there were no large accumulations or lack of aggregates throughout the planes. This EP distribution was significant since, in the case of a fissure, there should be a higher probability of rupture of capsules and subsequent release of healing product [6], [72], [73]. 


\section{CONCLUSIONS}

Strength resistance of the samples of this study denoted that the concentration of the bacterial solution encapsulated in the cementitious matrix did not affect performance. This was probably due to the lack of micro-organism activity since the samples were not fissured and no capsule rupture likely. Capillary absorption of water comparison across samples with varying levels of healing agent yielded a reduction in absorption after 42 days of healing. Sample BAC. 8 obtained the largest reduction in absorption, $43.45 \%$, while also presenting the highest visual efficiency with healing along the length of fissures, and thus, it is noticed its superior performance among others, considering the durability potential due to low absorption and its efficiency related to healing product formation. However, the width of fissure healed was equivalent in all samples with a maximum value of $0.22 \mathrm{~mm}$ and a single outlier result of $0.46 \mathrm{~mm}$. Microanalysis of EP inserted in the cementitious matrix observed void spaces with adequate dimensions to hold bacterial spores. Further SEM/EDS analysis confirmed effective EP impregnation with calcium lactate spraying. Samples presented a uniform EP distribution within the matrix which increased the probability that, upon formation of a fissure, capsule rupturing would be likely and healing agent released.

Overall, it could be concluded that the concentration of B. subtilis AP91 bacterial solution encapsulated in EP and coated in Portland cement did not affect the width of fissure healed. However, concentration did appear to have an effect in the length of fissure healed. It was unclear if the lower effectiveness of lower concentration samples was a result of the number of cells present lack of nutrients for bio-mineralization of calcium carbonate or uneven EP distribution in the cementitious matrix.

For this material to become viable on a large scale, both in financial and executive terms, conditions of use of bacterial solutions with less preparation must be evaluated, for example, invest in encapsulating the solution only by immersion, or analyze its use directly in the mixture water.

\section{REFERENCES}

[1] P. Patel, "Helping concrete heal itself," ACS Cent. Sci., vol. 1, no. 9, pp. 470-472, 2015, http://dx.doi.org/10.1021/acscentsci.5b00376.

[2] A. Carmona Fo. and T. G. Carmona, Fissuração nas Estruturas de Concreto. Mérida, México: ALCONPAT, 2013.

[3] M. Chemrouk, "The deteriorations of reinforced concrete and the option of high performances reinforced concrete," Procedia Eng., vol. 125, pp. 713-724, 2015, http://dx.doi.org/10.1016/j.proeng.2015.11.112.

[4] V. M. John, “Concreto sustentável,” in Concreto: Ciência e Tecnologia, G. C. Isaia, Ed. São Paulo, Brasil: IBRACON, 2011, pp. $1843-1869$.

[5] J. G. J. O. Olivier, G. Janssens-Maenhout, M. Muntean, and J. A. H. W. Peters, Trends in Global COz Emissions: 2014 Report. Hague, Netherlands: PBL, 2014.

[6] V. C. Li and E. Herbert, "Robust self-healing concrete for sustainable infrastructure," J. Adv. Concr. Technol., vol. 10, pp. 207-218, 2012., http://dx.doi.org/10.3151/jact.10.207.

[7] S. Sangadji, "Porous network concrete a bio-inspired building component o make concrete structures self-healing," Ph.D. dissertation, Institut Teknologi Bandung, Bandung, Indonesia, 2015.

[8] D. Gardner, R. Lark, T. Jefferson, and R. Davies, "A survey on problems encountered in current concrete construction and the potential benefits of self-healing cementitious materials," Case Stud. Constr. Mater., vol. 8, pp. 238-247, 2018, http://dx.doi.org/10.1016/j.cscm.2018.02.002.

[9] W. Celadyn, "Durability of buildings and sustainable architecture," Czas. Tech., vol. 7A, pp. 17-26, 2014.

[10] V. Wiktor and H. M. Jonkers, "Quantification of crack-healing in novel bacteria-based self-healing concrete," Cement Concr. Compos., vol. 33, pp. 763-770, 2011, http://dx.doi.org/10.1016/j.cemconcomp.2011.03.012.

[11] H. Huang, G. Ye, C. Qian, and E. Schlangen, "Self-healing in cementitious materials: materials, methods and service conditions," Mater. Des., vol. 92, pp. 499-511, 2016, http://dx.doi.org/10.1016/j.matdes.2015.12.091.

[12] J. Timerman, "Reabilitação e reforço de estruturas de concreto," in Concreto: Ciência e Tecnologia, G. C. Isaia, Ed., São Paulo, Brasil: IBRACON, 2011, pp. 1175-1209.

[13] K. van Breugel "Is there a market for self-healing cement-based materials?," First Int. Conf. Self Heal. Mater. Noordwijk aan Zee, The Netherlands, April 2007, pp. 1-9.

[14] L. Ferrara et al., "Experimental characterization of the self-healing capacity of cement based materials and its effects on the material performance: a state of the art report by COST Action SARCOS WG2," Constr. Build. Mater., vol. 167, pp. 115-142, 2018, http://dx.doi.org/10.1016/j.conbuildmat.2018.01.143.

[15] J. Zhang et al., "Immobilizing bacteria in expanded perlite for the crack self-healing in concrete," Constr. Build. Mater., vol. 148, pp. 610-617, 2017, http://dx.doi.org/10.1016/j.conbuildmat.2017.05.021. 
[16] S. Krishnapriya, D. L. V. Babu, and G. P. Arulraj, "Isolation and identification of bacteria to improve the strength of concrete," Microbiol. Res., vol. 174, pp. 48-55, 2015, http://dx.doi.org/10.1016/j.micres.2015.03.009.

[17] P. K. Mehta and P. J. M. Monteiro, Concreto Microestrutura, Propriedades e Materiais, 2nd ed. São Paulo: IBRACON, 2014.

[18] H. W. Reinhardt and M. Jooss, "Permeability and self-healing of cracked concrete as a function of temperature and crack width," Cement Concr. Res., vol. 33, no. 7, pp. 981-985, 2003, http://dx.doi.org/10.1016/S0008-8846(02)01099-2.

[19] M. S. Reddy, V. Achal, and A. Mukherjee "Microbial concrete, a wonder metabolic product that remediates the defects in building structures," in Microorganisms in Environmental Management: Microbes and Environment, T. Satyanarayana, B. N. Johri and A. Prakash, Eds., Dordrecht: Springer Netherlands, 2012, pp. 547-568.

[20] E. Schlangen, N. ter Heide, and K. van Breugel "Crack healing of early age cracks in concrete," in Measuring, Monitoring and Modeling Concrete Properties, M. S. Konsta-Gdoutos, Ed., Dordrecht: Springer Netherlands, 2007, p. $273-284$.

[21] A. Alyousif, "Self-healing capability of engineered cementitious composites incorporating different types of pozzolanic materials," Ph.D. dissertation, Ryerson University, Toronto, Canada, 2016.

[22] M. Şahmaran and V. C. Li, "Durability properties of micro-cracked ECC containing high volumes fly ash," Cement Concr. Res., vol. 39, no. 11, pp. 1033-1043, 2009, http://dx.doi.org/10.1016/j.cemconres.2009.07.009.

[23] R. Alghamri, A. Kanellopoulos, and A. Al-Tabbaa, "Impregnation and encapsulation of lightweight aggregates for self-healing concrete," Constr. Build. Mater., vol. 124, pp. 910-921, 2016., http://dx.doi.org/10.1016/j.conbuildmat.2016.07.143.

[24] H. Afifudin, W. Nadzarah, M. S. Hamidah, and H. Noor Hana, "Microbial participation in the formation of Calcium Silicate Hydrated (CSH) from Bacillus subtilis," Procedia Eng., vol. 20, pp. 159-165, 2011, http://dx.doi.org/10.1016/j.proeng.2011.11.151.

[25] J. Y. Wang, D. Snoeck, S. Van Vlierberghe, W. Verstraete, and N. De Belie, "Application of hydrogel encapsulated carbonate precipitating bacteria for approaching a realistic self-healing in concrete," Constr. Build. Mater., vol. 68, pp. 110-119, 2014, http://dx.doi.org/10.1016/j.conbuildmat.2014.06.018.

[26] S. Gupta, S. D. Pang, and H. W. Kua, "Autonomous healing in concrete by bio-based healing agents: a review," Constr. Build. Mater., vol. 146, pp. 419-428, Aug 2017, http://dx.doi.org/10.1016/j.conbuildmat.2017.04.111.

[27] L. Jiang, G. Jia, C. Jiang, and Z. Li, "Sugar-coated expanded perlite as a bacterial carrier for crack-healing concrete applications," Constr. Build. Mater., vol. 232, 2020, http://dx.doi.org/10.1016/j.conbuildmat.2019.117222.

[28] S. A. K. Zai and M. K. Murthy, "Self healing concrete," J. Civ. Eng. Environ. Technol., vol. 2, no. 16, pp. $27-33,2015$.

[29] M. T. Madigan, J. M. Martinko, K. S. Bender, D. H. Buckley, and D. A. Stahl Microbiologia de Brock, 14th ed. Porto Alegre: Grupo A Educação S.A., 2016.

[30] K. Vijay, M. Murmu, and S. V. Deo, "Bacteria based self healing concrete: a review," Constr. Build. Mater., vol. 152, pp. 10081014, 2017, http://dx.doi.org/10.1016/j.conbuildmat.2017.07.040.

[31] V. Müller, F. Pacheco, and B. Tutikian, "Técnicas e metodologias de biomineralização na cicatrização de fissuras do concreto," Rev. Arquitetura IMED, vol. 8, no. 2, pp. 164-182, 2019, http://dx.doi.org/10.18256/2318-1109.2019.v8i2.3679.

[32] F. Pacheco, “Análise da eficácia dos mecanismos de autocicatrização do concreto," Ph.D. dissertation, Universidade do Vale do Rio dos Sinos, São Leopoldo, Brasil, 2020.

[33] H. M. Jonkers, A. Thijssen, G. Muyzer, O. Copuroglu, and E. Schlangen, "Application of bacteria as self-healing agent for the development of sustainable concrete," Ecol. Eng., vol. 36, no. 2, pp. 230-235, 2010, http://dx.doi.org/10.1016/j.ecoleng.2008.12.036.

[34] M. Alazhari, T. Sharma, A. Heath, R. Cooper, and K. Paine, "Application of expanded perlite encapsulated bacteria and growth media for self-healing concrete," Constr. Build. Mater., vol. 160, pp. 610-619, Jan 2018, http://dx.doi.org/10.1016/j.conbuildmat.2017.11.086.

[35] H. M. Jonkers, "Bacteria-based self-healing concrete," Frankfurter Afrikanistische Blatter, vol. 8, no. 1, pp. 49-79, 2011.

[36] H. M. Jonkers and A. Thijssen "Bacteria mediated remediation of concrete strutures," in 2nd Int. Symp. Serv. Life Des. Infrastruct., October 2010, pp. 833-840.

[37] E. Tziviloglou, V. Wiktor, H. M. Jonkers, and E. Schlangen, "Bacteria-based self-healing concrete to increase liquid tightness of cracks," Constr. Build. Mater., vol. 122, pp. 118-125, 2016, http://dx.doi.org/10.1016/j.conbuildmat.2016.06.080.

[38] J. Wang, J. Dewanckele, V. Cnudde, S. Van Vlierberghe, W. Verstraete, and N. De Belie, "X-ray computed tomography proof of bacterial-based self-healing in concrete," Cement Concr. Compos., vol. 53, pp. 289-304, 2014, http://dx.doi.org/10.1016/j.cemconcomp.2014.07.014.

[39] J. Y. Wang, H. Soens, W. Verstraete, and N. De Belie, "Self-healing concrete by use of microencapsulated bacterial spores," Cement Concr. Res., vol. 56, pp. 139-152, 2014, http://dx.doi.org/10.1016/j.cemconres.2013.11.009.

[40] W. De Muynck, K. Cox, N. De Belie, and W. Verstraete, "Bacterial carbonate precipitation as an alternative surface treatment for concrete," Constr. Build. Mater., vol. 22, no. 5, pp. 875-885, 2008, http://dx.doi.org/10.1016/j.conbuildmat.2006.12.011.

[41] R. Pei, J. Liu, S. Wang, and M. Yang, "Use of bacterial cell walls to improve the mechanical performance of concrete," Cement Concr. Compos., vol. 39, pp. 122-130, 2013, http://dx.doi.org/10.1016/j.cemconcomp.2013.03.024. 
[42] M. Alazhari, T. Sharma, A. Heath, R. Cooper, and K. Paine, "Application of expanded perlite encapsulated bacteria and growth media for self-healing concrete," Constr. Build. Mater., vol. 160, pp. 610-619, 2017, http://dx.doi.org/10.1016/j.conbuildmat.2017.11.086.

[43] J. Wang, K. Van Tittelboom, N. De Belie, and W. Verstraete, "Use of silica gel or polyurethane immobilized bacteria for self-healing concrete," Constr. Build. Mater., vol. 26, no. 1, pp. 532-540, 2012, http://dx.doi.org/10.1016/j.conbuildmat.2011.06.054.

[44] J. Wang, H. M. Jonkers, N. Boon, and N. De Belie, "Bacillus sphaericus LMG 22257 is physiologically suitable for self-healing concrete," Appl. Microbiol. Biotechnol., vol. 101, no. 12, pp. 5101-5114, 2017, http://dx.doi.org/10.1007/s00253-017-8260-2.

[45] J. Xu and X. Wang, "Self-healing of concrete cracks by use of bacteria-containing low alkali cementitious material," Constr. Build. Mater., vol. 167, pp. 1-14, 2018, http://dx.doi.org/10.1016/j.conbuildmat.2018.02.020.

[46] N. Schwantes-Cezario, L. P. Medeiros, A. G. De Oliveira, G. Nakazato, R. Katsuko Takayama Kobayashi, and B. M. Toralles, "Bioprecipitation of calcium carbonate induced by Bacillus subtilis isolated in Brazil," Int. Biodeterior. Biodegradation, vol. 123, pp. 200-205, 2017., http://dx.doi.org/10.1016/j.ibiod.2017.06.021.

[47] A. F. Alshalif, J. M. Irwan, N. Othman, and L. H. Anneza "Isolation of Sulphate Reduction Bacteria (SRB) to improve compress strength and water penetration of bio-concrete," MATEC Web Conf., vol. 47, July 2016, pp. 01016.

[48] G. Souradeep and H. W. Kua, "Encapsulation technology and techniques in self-healing concrete," J. Mater. Civ. Eng., vol. 25, pp. 864-870, October 2016, http://dx.doi.org/10.1061/(ASCE)MT.1943-5533.

[49] K. Sisomphon, O. Copuroglu, and A. Fraaij, "Application of encapsulated lightweight aggregate impregnated with sodium monofluorophosphate as a self-healing agent in blast furnace slag mortar," Heron, vol. 56, no. 1-2, pp. 17-36, 2011.

[50] A. Sidiq, R. Gravina, and F. Giustozzi, "Is concrete healing really efficient? A review," Constr. Build. Mater., vol. 205, pp. 257-273, 2019, http://dx.doi.org/10.1016/j.conbuildmat.2019.02.002.

[51] K. Van Tittelboom et al., "Comparison of different approaches for self-healing concrete in a large-scale lab test," Constr. Build. Mater., vol. 107, pp. 125-137, 2016, http://dx.doi.org/10.1016/j.conbuildmat.2015.12.186.

[52] R. Davies, T. Jefferson, and D. Gardner, "Development and testing of vascular networks for self-healing cementitious materials," $J$. Mater. Civ. Eng., vol. 33, no. 7, pp. 1-15, 2021, http://dx.doi.org/10.1061/(asce)mt.1943-5533.0003802.

[53] N. Schwantes-Cezario, G. S. F. Nogueira, and B. M. Toralles, "Biocimentação de compósitos cimentícios mediante adição de esporos de Bacillus subtilis AP91," Rev. Eng. Civ. IMED, vol. 4, no. 2, pp. 142-158, 2017, http://dx.doi.org/10.18256/23586508.2017.v4i2.2072.

[54] N. Schwantes-Cezario, M. F. Porto, G. F. B. Sandoval, G. F. N. Nogueira, A. F. Couto, and B. M. Toralles, "Effects of Bacillus subtilis biocementation on the mechanical properties of mortars," Rev. IBRACON Estrut. Mater., vol. 12, no. 1, pp. 31-38, 2019, http://dx.doi.org/10.1590/s1983-41952019000100005.

[55] American Society for Testing and Materials, ASTM C33/C33M - Standard Specification for Concrete Aggregates, 2018.

[56] American Society for Testing and Materials, ASTM C595/C595M - Standard Specification for Blended Hydraulic Cements, 2020.

[57] American Society for Testing and Materials, ASTM D5550 - Standart Test Method for Specific Gravity of Soil Solids by Gas Pycnometer, 2014.

[58] American Society for Testing and Materials, ASTM C128 - Standard Test Method for Relative Density (Specific Gravity) and Absorption of Fine Aggregate, 2015.

[59] American Society for Testing and Materials, ASTM C29/C29M - Standard Test Method for Bulk Density ('Unit Weight') and Voids in Aggregate, 2017.

[60] K. M. J. Swanson, R. L. Petran, and J. H. Hanlin "Culture methods for enumeration of microorganisms," in Compendium of Methods for the Microbiological Examination of Foods, 4th ed., F. P. Downes and K. Ito, Eds. Washington, DC, United States: APHA, 2001, pp. 53-62.

[61] American Society for Testing and Materials, ASTM C31/C31M - Standard Practice for Making and Curing Concrete Test Specimens in the Field 2019.

[62] American Society for Testing and Materials, ASTM C348 - Standard Test Method for Flexural Strength of Hydraulic-Cement Mortars, 2020.

[63] R. Alghamri, A. Kanellopoulos, and A. Al-Tabbaa, "Impregnation and encapsulation of lightweight aggregates for self-healing concrete," Constr. Build. Mater., vol. 124, pp. 910-921, 2016, http://dx.doi.org/10.1016/j.conbuildmat.2016.07.143.

[64] RILEM TC 116-PCD, "Permeability of concrete as a criterion of its durability," Mater. Struct., vol. 32, pp. 174-179, 1999.

[65] American Society for Testing and Materials, ASTM C39/C39M - Standard Test Method for Compressive Strength of Cylindrical Concrete Specimens, 2020.

[66] M. M. Pelletier, R. Brown, A. Shukla, and A. Bose, "Self-healing concrete with a microencapsulated healing agent," Cement Concr. Res., 2011.

[67] R. Siddique et al., "Effect of bacteria on strength, permeation characteristics and micro-structure of silica fume concrete," Constr. Build. Mater., vol. 142, pp. 92-100, 2017, http://dx.doi.org/10.1016/j.conbuildmat.2017.03.057. 
[68] B. Hilloulin, D. Hilloulin, F. Grondin, A. Loukili, and N. De Belie, "Mechanical regains due to self-healing in cementitious materials: Experimental measurements and micro-mechanical model," Cement Concr. Res., vol. 80, pp. 21-32, 2016, http://dx.doi.org/10.1016/j.cemconres.2015.11.005.

[69] W. Khaliq and M. B. Ehsan, "Crack healing in concrete using various bio influenced self-healing techniques," Constr. Build. Mater., vol. 102, pp. 349-357, 2016, http://dx.doi.org/10.1016/j.conbuildmat.2015.11.006.

[70] J. Parks, M. Edwards, P. Vikesland, and A. Dudi, "Effects of bulk water chemistry on autogenous healing of concrete," J. Mater. Civ. Eng., vol. 22, no. 5, pp. 515-524, 2010, http://dx.doi.org/10.1061/(ASCE)MT.1943-5533.0000082.

[71] S. A. L. De Koster, R. M. Mors, H. W. Nugteren, H. M. Jonkers, G. M. H. Meesters, and J. R. Van Ommen, "Geopolymer coating of bacteria-containing granules for use in self-healing concrete," Procedia Eng., vol. 102, pp. 475-484, 2015, http://dx.doi.org/10.1016/j.proeng.2015.01.193.

[72] A. Al-Tabbaa, C. Litina, P. Giannaros, A. Kanellopoulos, and L. Souza, "First UK field application and performance of microcapsule-based self-healing concrete," Constr. Build. Mater., vol. 208, pp. 669-685, 2019., http://dx.doi.org/10.1016/j.conbuildmat.2019.02.178.

[73] D. Snoeck, J. Dewanckele, V. Cnudde, and N. De Belie, "X-ray computed microtomography to study autogenous healing of cementitious materials promoted by superabsorbent polymers," Cement Concr. Compos., vol. 65, pp. 83-93, 2016, http://dx.doi.org/10.1016/j.cemconcomp.2015.10.016.

Author contributions: VM: experimental procedure, materials characterization, writing; FP: experimental procedure, writing, revising; CMC: experimental procedure, materials characterization; FF: experimental procedure, materials characterization; VHV: writing, revising; RCEM: writing, revising; HZE: writing, revising ; BFT: supervision, revising, formal analysis.

Editors: Mark Alexander, Guilherme Aris Parsekian. 